\title{
Determination of Firm Value in Indonesia
}

\author{
LISTIYANA \\ STIE Gempol Pasuruan, East Java, Indonesia
}

\begin{abstract}
The purpose of this study is to determine the significance of the effect of dividend policy on firm value. This research was conducted on property and real estate companies on the Indonesia Stock Exchange for the period 2014-2018 where the number of samples taken was 31 companies. Determination of the sample in this study using the purpose sampling method. The data analysis technique used is simple regression. The results showed that dividend policy affected the value of real estate and property companies in Indonesia. Based on the results of this study, it is expected that companies can increase prosperity to shareholders by taking into account the company's growth which shows the company is in good condition in the future.
\end{abstract}

Keywords: firm value, dividend policy, dividend payout ratio, divident yield, price book value

DOI: $10.7176 / \mathrm{EJBM} / 11-15-02$

Publication date:May $31^{\text {st }} 2019$

\section{Introduction}

Firm value is an important concept for investors, because it is an indicator for the market to assess the company as a whole. Based on the firm value, investors can also predict the value of shares that are undervalued and overvalued, so that investors can determine the investment strategy as expected. One of the factors that influence firm value is dividend policy. The firm value is very important because the high firm value will be followed by the high prosperity of shareholders (Brigham, 1996). Firm value not only reflects the company's current performance but also projects the company's prospects in the future. Firm value is an important concept for investors, because it is an indicator for the market to assess the company as a whole (Mahendra, 2012). According to Oka (2011) firm value is the market value of a company's securities coupled with the value of debt. There are several factors that influence the firm value, namely funding decisions, dividend policy, investment decisions, capital structure, company growth and company size, some of these factors have a relationship and influence on inconsistent firm values (Mahendra, 2012)

Dividend policy can also be information for investors. The ability of a company to pay dividends is closely related to the company's ability to make a profit. Some investors expect returns in the form of dividends because investors think that dividends can reduce the risk of uncertainty in investing. However, not all investors expect fixed dividends from capital gains. On the grounds that capital gains are subject to a lower tax than the dividend and the tax payment can be delayed until the shares are sold. Dividend policy is not a standard in measuring a company's profitability, because not all bona fide companies always distribute dividends. Usually companies that do not distribute dividends prefer to make profits earned into retained earnings to be used for company expansion.

Dividend policy is a policy or decision whether the profits obtained by the company are shared with shareholders as dividends (divident payout ratio) or held up, in the form of retained earnings for future investment financing (Weston and Copeland, 1992). The dividend payment policy has an influence on shareholders and companies that pay dividends. The ability of a company to pay dividends is closely related to the company's ability to make a profit. If the company earns high profits, then the company's ability to pay dividends is also high, with high dividend payments increasing the firm value (Harjito and Martono, 2005).

Dividend payments according to Megginson (1997) are very expensive both for companies that make payments, because dividend payments will reduce the amount of funds used for investment, as well as for shareholders who receive dividend payments, because they have to pay taxes. This shows that only healthy and strong companies can afford to pay dividends. If the company has large total assets, the management is more free to use the assets in the company, the ease with which it controls the company will increase the firm value.

For investors, a stable dividend payment is a stable indicator of the company's prospects and thus the company's risk is also relatively lower compared to companies that are not stable in paying dividends. because investors prefer certainty about returns on their investments and anticipate the risk of uncertainty about the company's bankruptcy. High dividends will make investors interested in owning the company's shares, so that it can increase stock demand. High demand for shares will make investors appreciate the value of shares greater than the value recorded on the company's balance sheet, so that the company's PBV is high and the firm value is high. The research question in this study is how dividend policy affects the firm value in Indonesia.

\section{Literature Review And Hypotheses}

According to Sujoko and Soebiantoro (2007) firm value is an investor's perception of the level of success of the company associated with its stock price, high stock prices make the firm value also high. This will increase market 
confidence, not only on the company's current performance but also on the company's prospects in the future. Firm value will be reflected in the company's stock price or when the company provides returns to its investors.

Therefore maximizing the firm value is the same as maximizing the company's stock price. Soliha and Taswan (2002) state that the higher the stock price means the higher the firm value. According to Christiawan and Tarigan (2007) there are several concepts of corporate value, the first is the concept of nominal value, which is the value formally stated in the articles of association of the company. Second, the concept of market value called Exchange Rate is the price that occurs from the process of bargaining in the stock market. Third, the concept of intrinsic value is a value that refers to the estimated real firm value. Fourth, book value is the firm value calculated on the basis of accounting concepts. Finally, the concept of liquidation value is the selling value of all company assets after deducting all obligations that must be fulfilled.

According to Husnan and Pujiasti (2006) the firm value can be reflected in three ways, namely: book value, liquidation value, and stock market value. The firm value in this study is proxyed by price book value (PBV), which is the ratio of stock prices to the book firm value. Price Book Value (PBV) is a market ratio (market ratio) used to measure the performance of stock market prices on the value of the book. According to Ang (1997) simply states that Price Book Value (PBV) is a market ratio used to measure the performance of stock market prices on the value of the book. Price Book Value (PBV) shows the ability of a company to create firm value in the form of prices for available capital. With the higher PBV means the company can be said to succeed in creating value and prosperity for the owners of the company and shareholders of the company.

Dividend policy is a decision to reinvest profits obtained from the results of the company's operations or to share them with shareholders (investors). the profits gained by market participants in investing in shares can come from capital gains and dividends. The difference between the two is that capital gains are profits derived from increases in changes in stock prices. Or the advantage of the difference between buying and selling prices of shares. Generally investors with a short-term orientation to pursue profits are by obtaining returns from capital gains. Dividends are a portion of company profits that are distributed to shareholders. Obtain dividends by buying shares of a company that has been listed on the stock exchange.

To get dividends, investors must save the shares until they pass the cum date dividend. Cum date is the date of recording of investors entitled to receive dividends. Dividends are returns that are reserved for long-term stock investors. Dividend policy is reflected in the divident payout ratio (DPR) and dividend yield (DY), which is the percentage of profit distributed in the form of cash dividends. Retained earnings is one of the important sources of funds to finance the growth of the company. Dividend policy is the decision to share profits or hold them to be reinvested in the company. Some theories can be used as a basis for making dividend policy for the company.

Several theories of dividend policy according to Brigham and Houston (2006) :

1. Dividend Irrelevant theory. This theory states that the distribution of profits in the form of dividends is less relevant to the increase or increase in investor wealth, because dividends are a small part of the company's funding decisions. While investors in general expect the return of their total investment either from dividends or from capital gains. There is another opinion that dividends are good for investors when conditions are uncertain, this is related to the opinion that the firm value in general is determined by the ability of the company's assets to generate profits or the accuracy of company management in investing.

2. Birds-in-Hand-theory. The theory put forward by Gordon (1959) and Litner (1956), which argues that equity or firm value will decrease, if the dividend payout ratio is increased, because investors are less convinced of the capital gains generated from profits detained compared to if investors receive dividends. They argue that investors are actually far more appreciative of the expected income from dividends than expected income from capital gains, because the component of dividend yields is less than the component of capital gains. Modigliani and Miller (1963) in this case do not agree, that equity or firm value does not depend on dividend policy, which implies that investors do not care about dividends with capital gains. MM named GordonLintner's opinion as a mistake in the bird-in-the-hand theory, namely: based on the idea that investors view one bird in the hand as more valuable than a thousand birds in the air. Thus, companies that have a high dividend payout ratio will have high corporate value.

3. Signaling theory. The first time triggered by Bhattacharya (1979) underlies the notion that, announcements of changes in cash dividends have information content, which results in the reaction of stock prices. This theory explains that information about the cash dividend paid is considered by investors as a signal of the company's prospects in the future. This assumption is due to the occurrence of asimetric information between managers and investors, so investors use dividend policy as a signal about the company's prospects. If there is an increase in dividends, it will be considered as a positive signal, which means the company has good prospects, giving rise to a positive stock price reaction. Conversely, if the decrease in dividends will be considered as a negative signal, it means that the company has a poor prospect, giving rise to a negative stock price reaction. Information asymmetry needs to be minimized, because investors always need symmetrical information as monitoring in investing funds in a company. One type of information issued by companies that can be signaled to parties outside the company, especially for investors is the annual report. Information disclosed in annual 
reports can be in the form of accounting, namely information relating to financial statements. Annual reports should contain information that is considered important to report users, both inside and outside parties. All investors need information to evaluate the relative risks of each company so they can diversify their portfolios and investment combinations with the desired risk preferences. If the company wants its shares to be sold, the company must disclose financial statements openly and transparently

The dividend policy in this study is proxied by dividend payout ratio (DPR) and dividend yield (DY). The dividend policy is reflected in the divident payout ratio (DPR) and dividend yield (DY). Dividends indicate the prospect of profits that will be achieved by the company in the future. So that made a measure by investors who want to invest. According to Soemarso (2005: 193) dividends are the distribution of profits to owners of limited liability companies. With high dividend payments will increase the firm value (Harjito and Martono, 2010: 23).

Dividend is a return that is anticipated by investors and signals that the company is in a position of high profitability (Ria, 2013). Some important factors that influence dividend policy are investment opportunities, the availability of capital costs and the preference of shareholders to receive income now or in the future. Divident Payout Ratio (DPR) is the percentage of profit distributed in the form of cash dividends. Dividend yield (DY) is a way to determine how much a company is distributing dividends to shareholders seen from the current stock price.

Ria Nofrita (2013) concluded that simultaneously the variables of profitability and dividend policy have a significant positive effect on firm value. partially the profitability variable does not have a significant effect on the dividend policy variable. Another case with Dwi Ayuningtias's research (2014) which states that dividend policy is not proven to have a significant positive effect on firm value. Therefore the hypothesis in this study is that dividend policy has a positive effect on firm value.

\section{Research Methods}

This study uses an explanatory descriptive method approach to explain the influence between the independent variables, namely dividend policy on the dependent variable, namely company value. Data is obtained from publicly listed companies listed on the Indonesia Stock Exchange which provide financial statements in a row in the 2014-2018 period. The method of determining samples from population by means of sampling is the criteria of property and real estate companies listed on the Indonesia Stock Exchange and issuing financial statements in a row in the 2014-2018 period. The data used is secondary data accessed from the official website of the Indonesia Stock Exchange Data analysis was carried out by simple regression.

The dependent variable in this study is firm value, which in this study is operationalized as a market value or value in the amount of money where the buyer is willing to pay when the company is sold (Husnan, 2004). The firm value is proxied by Price Book Value (PBV), which is the market ratio used to measure the price of a stock to its book value. The measurement is by comparing the price of one share with the value (nominal) of a share, expressed in percent, the stock price is the clossing price Ang (1997). PBV is formulated as:

Price to Book Value $(\mathrm{PBV})=($ Stock Price per Share / Book Vale Per Share) $\mathrm{x} 100 \%$

While the independent variable is a dividend policy which in this study is operationalized by dividing profits to the shareholders of the company which is proportional to the number of sheets owned. According to Hanafi (2012: 361) dividends are compensation received by shareholders, in addition to capital gains. While the dividend policy according to Martono and Harjito (2010: 253), is a decision whether the profits obtained by the company at the end of the year will be shared with shareholders in the form of dividends or will increase capital for investment financing in the future. Dividend Payout Ratio is the percentage of profit distributed in the form of cash dividends. The dividend policy is proxied by dividend payout ratio (DPR) and Dividend yield (DY), the stock price is the closing price. Dividend Payout Ratio (DPR) can be formulated as:

Dividend Payout Ratio $=($ Devidend per share $/$ Earning per share $) \times 100 \%$

Dividend Yield can be formulated as:

$$
\text { Dividend Yield }=(\text { Dividend per Share } / \text { Market Value per Share }) \times 100 \%
$$

\section{Result}

The study to prove the effect of dividend policy that is proxied by the Divident Payout Ratio and Yield Dividend on the firm value that is proxied by the Price Book Value (PBV). The results of the descriptive statistical test show that the average value of the variable firm value is 1.9897 with a standard deviation of 1.16969 . from this value it can be concluded that there are no large fluctuations in the property and real estate sub-sector companies listed on the Indonesia Stock Exchange in the 2014-2018 period which were sampled in this study as seen in table 1.

Tabel 1. Descriptive Statistics

\begin{tabular}{|l|l|l|l|}
\hline & Mean & Std. Deviation & $\mathrm{N}$ \\
\hline Firm Value & 1.9897 & 1.16996 & 31 \\
\hline Divident Policy & 47.7342 & 71.35682 & \\
\hline
\end{tabular}

The average value of the dividend policy variable is 47.7342 with a standard deviation of 71.35682 . With a standard deviation value that is greater than the average value in the dividend policy variable, it can be stated that 
there are fluctuations in dividend policy. In property and real estate companies that are listed on the Indonesia Stock Exchange in the 2014-2018 period, this occurs because the conditions are less stable at that time, as seen in table 1 .

The lowest value Dividend policy proxied by the 2014 Devident Payout Ratio (DPR) of 0.1 by PT. ASRI, 2015 amounted to 3.1 by PT. RDTX, in 2016 amounted to 1.24 by PT. DILD, 2017 amounting to 1.7 by PT. RDTX, 2018 amounting to 1.6 by PT. RDTX. While the highest value of dividend policy proxied with dividend Payout Ratio is 2014 amounted to 32.7 by PT. JPT, in 2015 amounted to 58.2 by PT. PLIN, in 2016 amounted to 106 by PT. MPI, in 2017 amounted to 1351 by PT. KIJA, in 2018 it is 96.2 by PT .CTRP

Dividend policy is considered important for several companies and investors, because the purpose of dividend payments or dividend receipts by investors is to give signals to investors about the company's success in earning profits. There are some investors who prefer the return on investment in the form of dividends because they reduce the risk of uncertainty in investing even though dividends are taxed. However, there are investors who prefer the return obtained from capital gains, with the reason that the tax from capital gains can be delayed by the tax payment until the shares owned by investors (shareholders) are sold.

Tabel 2. Dividend Ratio which is proxied Dividend Payout Ratio

\begin{tabular}{|c|c|c|c|c|c|c|}
\hline \multicolumn{7}{|c|}{ Devidend Payout Ratio } \\
\hline \multicolumn{7}{|c|}{ Year } \\
\hline No & Company & 2014 & 2015 & 2016 & 2017 & 2018 \\
\hline 1 & ACST & 17,2 & 15,6 & 19,9 & 20,1 & 14,4 \\
\hline 2 & ADHI & 3,27 & 20 & 30 & 19,7 & 20,1 \\
\hline 3 & APLN & 17,2 & 14,6 & 14,5 & 64,3 & 29,4 \\
\hline 4 & ASRI & 0,1 & 24,1 & 32,7 & 11,7 & 6,76 \\
\hline 5 & BKSL & 9,87 & 11,1 & 8,68 & 14,7 & 9 \\
\hline 6 & BSDE & 8,75 & 20,4 & 9,75 & 7,21 & 4,5 \\
\hline 7 & CTRA & 32,7 & 30,9 & 29,5 & 925 & 25,7 \\
\hline 8 & CTRP & 28,4 & 30,8 & 30,6 & 581 & 96,2 \\
\hline 9 & CTRS & 0,9 & 30,3 & 29,7 & 9,86 & 8,67 \\
\hline 10 & DART & 30,3 & 48,6 & 48,7 & 15,2 & 28,5 \\
\hline 11 & DGIK & 15,4 & 23,4 & 21 & 3,7 & 5,47 \\
\hline 12 & DILD & 0,69 & 25,9 & 1,24 & 1,39 & 1,98 \\
\hline 13 & EMDE & 5,03 & 3,69 & 3,03 & 7,48 & 5,21 \\
\hline 14 & GMTD & 6,53 & 7,89 & 5,52 & 5,42 & 4,32 \\
\hline 15 & JRPT & 32,4 & 34,1 & 34 & 30,6 & 33,2 \\
\hline 16 & KIJA & 07.25 & 7,01 & 6,76 & 1351 & 8,47 \\
\hline 17 & LPCK & 4,85 & 3,56 & 2,79 & 2,19 & 1,35 \\
\hline 18 & LPKR & 0,96 & 25,8 & 26,4 & 10,5 & 15,1 \\
\hline 19 & MDLN & 0,79 & 1,64 & 2,56 & 1,35 & 2,85 \\
\hline 20 & MKPI & 44 & 43,1 & 106 & 48,5 & 34,9 \\
\hline 21 & MTLA & 30 & 20 & 20,4 & 903 & 13,4 \\
\hline 22 & PLIN & 15,6 & 58,2 & 43,7 & 69,4 & 39.9 \\
\hline 23 & PTPP & 27,5 & 30 & 30 & 20 & 19,9 \\
\hline 24 & PUDP & 17,5 & 14,6 & 15 & 26,3 & 21,3 \\
\hline 25 & PWON & 15,5 & 22,5 & 19,1 & 8,62 & 17,2 \\
\hline 26 & RDTX & 3,4 & 3,1 & 14,2 & 1,7 & 1,6 \\
\hline 27 & SMRA & 11,7 & 38,9 & 30,1 & 49,1 & 8,43 \\
\hline 28 & SSIA & 18,6 & 19,1 & 18,9 & 15,5 & 15 \\
\hline 29 & TOTL & 3,62 & 55 & 56 & 62,5 & 71,3 \\
\hline 30 & WIKA & 25,6 & 29,8 & 30 & 20 & 20 \\
\hline 31 & WSKT & 11,2 & 8 & 30 & 19,9 & 20 \\
\hline
\end{tabular}

From table 3 it can be seen that the lowest value of dividend policy proxied by 2014 dividend yield (DY) is 0.6 by PT. LPCK, in 2015 amounted to 0.47 by PT. WSKT, in 2016 amounted to 0.18 by PT. KIJA, in 2017 amounted to 0.24 by PT. BSKL, in 2018 amounting to 0.3 by PT. Middle School The highest value of dividend policy proxied by dividend yield is 2014 amounted to 45.9 by PT. SMARA, in 2015 amounted to 7.58 by PT. GMTD in 2016 amounted to 6.29 by PT.DART, in 2017 amounting to 89.2 by PT.KIJA, in 2018 it is 3.65 by PT .CTRP. 
Tabel 3. Dividend Policy Ratio which is proxied by Divident Yield

\begin{tabular}{|c|c|c|c|c|c|c|}
\hline \multicolumn{7}{|c|}{ Dividend Yield } \\
\hline \multicolumn{7}{|c|}{ Year } \\
\hline No & Company & 2014 & 2015 & 2016 & 2017 & 2018 \\
\hline 1 & ACST & 1,09 & 1,63 & 1,98 & 1,13 & 1,3 \\
\hline 2 & $\mathrm{ADHI}$ & 1,1 & 1,33 & 4,48 & 1,03 & 1,23 \\
\hline 3 & APLN & 1,71 & 1,62 & 2,79 & 1,45 & 1,89 \\
\hline 4 & ASRI & 3,45 & 2,43 & 1,19 & 1,25 & 1,77 \\
\hline 5 & BKSL & 7,98 & 1,65 & 1,23 & 0,24 & 0,65 \\
\hline 6 & BSDE & 2,15 & 1,35 & 1,16 & 0,83 & 1,51 \\
\hline 7 & CTRA & 1,3 & 1,5 & 2,53 & 4,55 & 2,1 \\
\hline 8 & CTRP & 1,63 & 2,67 & 3,39 & 44 & 3,65 \\
\hline 9 & CTRS & 2,87 & 1,87 & 4,58 & 0,88 & 1,04 \\
\hline 10 & DART & 2,66 & 3,94 & 6,29 & 4,35 & 2,85 \\
\hline 11 & DGIK & 1,66 & 1,39 & 1,67 & 2,31 & 1,81 \\
\hline 12 & DILD & 1,18 & 1,49 & 1,82 & 2 & 1,08 \\
\hline 13 & EMDE & 0,82 & 1,36 & 1,22 & 0,73 & 0,86 \\
\hline 14 & GMTD & 5,76 & 7,58 & 0,6 & 1,07 & 1,32 \\
\hline 15 & JRPT & 1,83 & 1,71 & 1,69 & 1,87 & 2,82 \\
\hline 16 & KIJA & 0,85 & 0,67 & 0,18 & 89,2 & 0,56 \\
\hline 17 & LPCK & 0,6 & 0,57 & 0,53 & 0,38 & 0,84 \\
\hline 18 & LPKR & 01.09 & 1,19 & 1,54 & 0,86 & 0,34 \\
\hline 19 & MDLN & 0,96 & 1,33 & 1,28 & 1,05 & 1,62 \\
\hline 20 & MKPI & 5,17 & 4,23 & 4,32 & 1,46 & 1,94 \\
\hline 21 & MTLA & 15,6 & 0,99 & 1,71 & 82,8 & 1,95 \\
\hline 22 & PLIN & 1,98 & 2,62 & 1,69 & 1,87 & 1,83 \\
\hline 23 & PTPP & 2,71 & 2,31 & 2,25 & 0,61 & 1,21 \\
\hline 24 & PUDP & 2,85 & 1,98 & 2,5 & 2,72 & 2,33 \\
\hline 25 & PWON & 1,89 & 1,56 & 1,67 & 0,87 & 0,91 \\
\hline 26 & RDTX & 1,86 & 1,97 & 2,14 & 1,95 & 2 \\
\hline 27 & SMRA & 45,9 & 2,26 & 2,95 & 1,38 & 0,3 \\
\hline 28 & SSIA & 1,53 & 2,78 & 5,36 & 1,85 & 1,01 \\
\hline 29 & TOTL & 5,2 & 3,26 & 7 & 2,68 & 6,5 \\
\hline 30 & WIKA & 1,65 & 1,51 & 1,76 & 0,54 & 0,77 \\
\hline 31 & WSKT & 0,86 & 0,47 & 2,83 & 0,7 & 0,92 \\
\hline
\end{tabular}

Dividend yield is part of the total return that investors will get. Usually companies that have high growth prospects will have a low dividend yield, because most dividends will be reinvested, and also because of the high dividend tax which will cause the dividend yield to be small. Conversely, companies that have low growth prospects will provide high dividends and thus have high dividend yields as well. Dividend yield shares are only estimates of dividends as a proportion of stock prices. 
Tabel 4. Firm Value Ratio which is proxied by Price Book Value

\begin{tabular}{|c|c|c|c|c|c|c|}
\hline \multicolumn{7}{|c|}{ PBV } \\
\hline \multicolumn{7}{|c|}{ Year } \\
\hline No & Company & 2011 & 2012 & 2013 & 2014 & 2015 \\
\hline 1 & ACST & 2,06 & 1,22 & 1,78 & 3,04 & 3,58 \\
\hline 2 & ADHI & 1,58 & 2,68 & 1,76 & 4,1 & 1,48 \\
\hline 3 & APLN & 1,43 & 1,19 & 0,61 & 0,87 & 0,9 \\
\hline 4 & ASRI & 1,72 & 2,49 & 1,58 & 1,81 & 1,01 \\
\hline 5 & BKSL & 1,81 & 1,23 & 0,72 & 0,47 & 0,44 \\
\hline 6 & BSDE & 1,75 & 1,84 & 1,68 & 1,89 & 1,57 \\
\hline 7 & CTRA & 1,07 & 1,43 & 1,16 & 1,78 & 1,35 \\
\hline 8 & CTRP & 0,84 & 0,93 & 0,83 & 1,11 & 0,67 \\
\hline 9 & CTRS & 0,88 & 2,01 & 1,04 & 2,1 & 1,64 \\
\hline 10 & DART & 0,55 & 0,79 & 0,48 & 0,68 & 0,74 \\
\hline 11 & DGIK & 0,51 & 0,79 & 0,78 & 0,9 & 0,59 \\
\hline 12 & DILD & 0,7 & 0,88 & 0,8 & 1,56 & 1,27 \\
\hline 13 & EMDE & 0,99 & 0,9 & 0,67 & 0,78 & 0,81 \\
\hline 14 & GMTD & 0,39 & 0,29 & 2,09 & 1,29 & 1,29 \\
\hline 15 & JRPT & 2,87 & 3,84 & 4,1 & 4,74 & 2,47 \\
\hline 16 & KIJA & 0,82 & 1 & 0,93 & 1,31 & 1,03 \\
\hline 17 & LPCK & 1,52 & 1,83 & 1,87 & 2,9 & 1,8 \\
\hline 18 & LPKR & 1,53 & 2,01 & 1,48 & 1,44 & 1,26 \\
\hline 19 & MDLN & 1,82 & 1,72 & 1,05 & 1,26 & 0,97 \\
\hline 20 & MKPI & 3,35 & 2,16 & 4,69 & 7,14 & 5,66 \\
\hline 21 & MTLA & 1,86 & 2,63 & 1,63 & 1,76 & 0,74 \\
\hline 22 & PLIN & 2,45 & 2,58 & 3,16 & 5,8 & 5,9 \\
\hline 23 & PTPP & 2,71 & 2,43 & 2,83 & 8,06 & 3,67 \\
\hline 24 & PUDP & 0,54 & 0,61 & 0,57 & 0,51 & 0,44 \\
\hline 25 & PWON & 3,15 & 3,46 & 3,17 & 4,57 & 2,53 \\
\hline 26 & RDTX & 1,53 & 0,99 & 1,15 & 1,09 & 1,01 \\
\hline 27 & SMRA & 0,41 & 3,59 & 2,42 & 4 & 3,16 \\
\hline 28 & SSIA & 2,35 & 3,04 & 1,01 & 1,83 & 1,01 \\
\hline 29 & TOTL & 5,1 & 4,35 & 2,08 & 4,73 & 2,42 \\
\hline 30 & WIKA & 2,78 & 3,21 & 3,01 & 4,79 & 2,99 \\
\hline 31 & WSKT & 3,37 & 2,16 & 1,64 & 5,9 & 2,34 \\
\hline
\end{tabular}

The lowest value of firm value proxied by the 2014 Price Book Value (PBV) of 0.1 by PT. RDTX, in 2015 amounted to 0.21 by PT. RDTX, in 2016 amounted to 0.186 by PT. RDTX, 2017 is 0.18 by PT. RDTX, 2018 is 0.31 by PT. PUDP While the highest value of firm value proxied by Price Book Value (PBV) is 2014 at 7.24 by PT.WSKT, in 2015 it was 5.67 by PT. ADHI, in 2016 amounted to 5.28 by PT. ADHI, year 2017 amounting to 5.11 by PT. PP, 2018 amounting to 2.29 by PT. TOTL. (see table 4.)

The results of the normality test are seen from the histogram graph analysis. indicates that the variable is normally distributed with a mean of 2.57 , a standard deviation value of 0.949 for a sample of 31 companies. The multicollinearity test for dividend policy shows the variance inflation factor (VIF) value of 1.062 and the tolerance value of 0.942 , meaning that there is no multicollinearity in the regression model. The results of heteroscedasticity tests with scatterplots conducted show the results that the dividend policy variable is above and below the number 0 on the axis of the firm value variable. The autocorrelation test results were carried out with Durbin-Watson in the amount of 1.960 where the number was between 0 and 4 . The results showed that in this study there was no autocorrelation. The results of a simple regression test show that unstandardized coefficients for constants are 0.167 and the dividend policy variable is 0.001 so that the regression equation can be written as follows:

Firm Value $=0.167+0,001$ Devidend Policy $+\mathrm{e}$

It can be seen that the dividend policy variable is less or no effect on company value. The test results of the coefficient of determination can be interpreted that the value of the adjusted R2 value in the regression model of the property and Real Estate services company is 0.674 , indicating that there is a strong correlation with the dividend policy on firm value. The hypothesis test results of the influence of dividend policy on firm value indicate that the dividend policy variable has a significance value (sig) of 0.759 which means it is greater than the significance level $\alpha=0.005$. and has a t-count value of 0.309 and a t-table value of 2.042 . Thus the dividend policy variable has a t-count value $<$ t-table $(0.309<2.042)$, so that dividend policy does not affect the value of the firm. 
Dividends have measures that can be used as a measure in a company, namely Devident Payout Ratio (DPR) and Devident Yield (DY). Dividend is the return received by the investor from the percentage of income earned by the company from the available capital. In the financial analysis of dividend payout ratio (DPR) and dividend yield is a factor to determine the return of shares. All investors want a big return. Because there are some investors who think that getting a return will reduce the risk of uncertainty in investing. However, large dividends and dividend yields will have a negative impact on the capital stock. The yield dividend is used as an indicator of stock valuation which means that the greater the dividend yield means that the stock is undervalued.

Based on the results obtained from regression testing, a negative value on the Devidend Yield (DY) is obtained at -0.012 with a significance of 0.000 . This shows that the Devidend Yield (DY) has a negative effect on dividend policy. Simultaneously the indicators of dividend policy have no effect on dividend policy which causes a partial dividend policy to have no effect on company value. This is because investors in sample companies generally do not expect return from dividends but rather expect returns from capital gains. This is because the tax on profits distributed (dividends) causes investors to prefer capital gains because they can delay tax preference. So that returns from dividends do not affect investors in determining their choices for investing. Therefore in this study dividend policy does not affect the firm value .

\section{Conclusion}

From the results of hypothesis testing conducted shows that the company's dividend policy does not affect the firm value this will result in a decrease in the number of investors investing in issuers because they consider the company's financial performance in the eyes of investors is not good. It is expected that companies can increase prosperity to shareholders by taking into account the company's growth which shows the company is in good condition in the future by paying attention to other factors beyond dividend policy. The limitations of the research sector and the data saved make this research feasible to be reexamined for subsequent research.

\section{References}

Ang, Robert.1997. Buku Pintar Pasar Modal Indonesia. Jakarta: Media Staff Indonesia.

Ayuningtyas. Dewi. 2013. Pengaruh Profitabilitas Terhadap Nilai Perusahaan: Kebijakan Deviden dan Kesempatan Investasi Sebagai Variabel Antara. Jurnal STEIA. Surabaya.

Bhattacharya, S., 1979. Imperfect Information, Dividend Policy and the Bird in the Hand Fallacy Bell. Journal of Economics. Vol 10, pp 259-270.

Brigham E.. 2004. Fundamental of Financial Management theory, 6 ed, Harcourt Brace College Publising.

Brigham, Eugene, and Joel F. Houston. 2006. Fundamental of Financial Management, Tenth Edition, USA : Thomson South Westren College publishing.

Brigham, Eugene, and Joel F. Houston. 2001. Financial Management II. Jakarta: Salemba Empat.

Brigham, Eugene, and Joel F. Houston. 1999. Financial Management. Jakarta: Erlangga.

Brigham, Eugene, and Joel F. Houston 2001 Financial Management, 2th Edition. Jakarta: Penerbit Erlangga.

Brigham. Eugene. F and Louis. C Gapenski. 2006. Intermediate Financial Manajement $9^{\text {th }}$ Edition. New York.

Christiawan, Y.J. dan J. Tarigan. 2007. Kepemilikan Manajerial: Kebijakan Hutang, Kinerja dan Nilai Perusahaan. Jurnal Akuntansi dan Keuangan. Vol.1. mei 2007. Hal:1-8.

Gordon, Myron J., 1959. Dividends, earnings, and stock prices, Review of Economics and statistics, Volume 41, Page 99-105.

Hanafi, Mamduhdan Halim, Abdul. 2012. Analisis Laporan Keuangan. Edisi Ketiga. Cetakan Pertama. Yogyakarta: Penerbit UPP Sekolah Tinggi Ilmu Manajemen YKPN.

Harjito, Agus and Martono, SU. 2010.Manajemen Keuangan, Edisi Pertama, Cetakan Kedua. Yogyakarta.Penerbit Ekonisia.

Husnan, Suaddan Enny Pudjiastuti. 2006. Dasar-Dasar Manajemen Keuangan.Edisi Kelima.Yogyakarta:UPP STIM YKPN.

Husnan, Suad. 2001. Dasar-Dasar Teori Portofolio dan Analisis Sekuritas. Yogyakarta : Unit Penerbit dan Percetakan AMP YKPN.

Husnan, Suad. 2006. Manajemen Keuangan: Teori dan Penerapan. Buku 1, Edisi 4.Yogyakarta BPFE.

Lintner, J. 1956. Distribution of Incomes of Corporation among Dividends, Retained Earnings, and Taxes. The America Review, Vol. 46 No. 2. pp 97-113.

Mahendra, Alfredo; Artni, Luh Gede Sri and Suarjaya, A A Gede. 2012. Pengaruh Kinerja Keuangan terhadap Nilai Perusahaa Pada Perusahaan Manufaktur di Bursa Efek Indonesia. Jurnal Manajemen, Strategi Bisnis, dan Kewiausahaan Vol. 6 No. 2. pp 130-134.

Megginson. 1997. Corporate Finance Theory. Addison-Wesley Educational Publisher Inc.

Modigliani, F. and M.H. Miller. 1963, Corporate Income Taxes and the Cost of Capital: A Correction, American Economic Review 53, pp 433-443

Oka Kusumajaya, D.K. 2011. Pengaruh Struktur Modal dan Pertumbuhan Perusahaan terhadap Profitabilitas dan 
Nilai perusahaan pada Perusahaan Manufaktur di BEI. Tesis. Universitas Udayana.

Ria, Nofrita. 2013. Pengaruh Profitabilitas terhadap Nilai Perusahaan Dengan Kebijakan deviden Sebagai Variabel Intervening. Universitas Negeri Padang. Padang

Soemarso. 2005. Akuntansi Suatu Pengantar. Edisi Revisi. Jakarta: Salemba Empat

Soliha, E., dan Taswan. 2002. Pengaruh Kebijakan Hutang Terhadap Nilai Perusahaan Serta Beberapa Faktor Yang Mempengaruhinya. Jurnal Ekonomi dan Bisnis, STIE Stikubank Semarang, pp 1-18.

Sujoko dan Soebiantoro, U., 2007. Pengaruh Struktur Kepemilikan Saham, Leverage, Faktor Intern dan Faktor Ekstern terhadap Nilai Perusahaan. Jurnal Manajemen dan Kewirausahaan,Vol 9, 47.

Sunariyah, 2003. Pengantar Pengetahuan Pasar Modal, edisi ketiga. Yogyakarta :UPP-AMP YKPN,.

Weston, J. Fred and Copeland, Thomas E. 1992. Managerial Finance. Edisi kesembilan, The Dryden Press, A Harcourt Brace Jovanovic College Publisher, USA, Canada, Tokyo, etc. 